\title{
Aikuiskasvattajien koulutus kaipaa selvittelyä
}

Parin viime vuosikymmenen aikana on aikuiskasvatuksen ammattitehtäviin valmentava yliopistollinen peruskoulutus jatkuvasti yleistynyt niin Euroopassa kuin muuallakin. Yhä useampiin yliopistoihin on perustettu aikuiskasvatuksen virkoja ja laitoksia ja oppialaan erikoistuva opetus- ja tutkimustoiminta on asenneviiveistä ja taloudellisista vaikeuksista huolimatta edennyt lupaavasti.

Yleismaailmallista kehitystaustaa vasten vaikuttaa takaperoiselta että Suomessa, jossa aikuiskasvatuksella on oppiaineena jo suhteellisen pitkä perinne, on viime vuosina alettu tarjota pedagogiselle kasvatustieteelle perustuvia koulutusohjelmia myös aikuiskasvatustehtäviin valmentaviksi. Näin on järkiään tehty kasvatusalan hallinnon, suunnittelun ja tutkimuksen koulutusohjelmissa (lyhenne ''hastu'"), joita tutkinnonuudistuksen yhteydessä 1970-luvun lopulla perustettiin jokseenkin kaikkiin kasvatustieteellisiin laitoksiin. Kun hastu-koulutuksessa ilmenee voimistuvia paineita hakea työhön sijoittumisen mahdollisuuksia aikuiskasvatuksen ammattialoilta, on aiheellista kysyä, mikä on alan tosiasiallinen koulutustarve ja mi-. ten hastu-koulutuksessa hankitut valmiudet vastaavat aikuiskasvatustehtävien ammatillisia erityisvaatimuksia? Ensin muutama sana siitä, miten tähän on tultu.

Kasvatusalan tutkinnonuudistuksessa vei opettajankoulutus ymmärrettävästi päähuomion. Erityistä hallinnon ja suunnittelun asiantuntijatehtäviin suuntautuvaa koulutuslinjaa pidettiin tarpeellisena, mutta sen tehtäväalan määrittäminen ja koulutustarpeen arvioiminen jäi hyvin ylimalkaiseksi. Näin hastu-ohjelmia perustettiinkin kilvan pikemmin kasvatustieteellisten laitosten asemien ja ikiomien koulutusohjelmien turvaamiseksi kuin huolellisten tarvearviointien varassa. Koululaitoksen hallinto-ja suunnittelutehtävät olivat näiden ohjelmien luontevin ammatillinen kohdealue, mutta jo perustamisvaiheessa oli selvää, että koulutoimen kyseisten virkojen ja toimien lisääntyminen tulisi 1980-luvulla olemaan vähäistä. Näin hastu-ohjelmille, joissa koulutettavien valtakunnallinen kokonaismäärä liikkunee kahdensadan paikkeilla, on jouduttu hakemaan ammatillista tehtäväkenttää muun muassa ja erityisesti aikuiskasvatuksen piiristä.

Onko sitten aikuiskasvatuksen eri lohkoilla ja organisaatioissa odotettavissa sellaista päätoimisen hallintohenkilöstön tarvetta ja kysyntää, joka vastaisi tarjonnan huomattavaa laajentumista? Alan määrällisen ja laadullisen koulutustarpeen arvioiminen vaatii valtakunnallista selvitystä. Vapaassa sivistystyössä ja julkishallinnossa, joiden piirissä koulutustarve on helpoimmin arvioitavissa, ei p.o. virkoja ja toimia tulle lähitulevaisuudessa avautumaan montakaan kymmentä vuosittain. Yksityinen elinkeinoelämä on viime vuosina tarjonnut eniten aikuiskoulutuksen päätoimisia työtehtäviä, mutta ilman erityisselvitystä voi vain arvailla, kuinka pitkälle tämä kehityssuunta tulee jatkumaan ja millaisia koulutusvaatimuksia työhön otettaville asetetaan. 
Olettakaamme, että koulutustarpeen rajallisuus ei olisi mikään pulma vaan että aikuiskasvatuksen hallinto- ja suunnittelutehtäviin otettaisiin vuosittain esimerkiksi satakunta alalle erityiskoulutuksen hankkinutta maisteria. Tavoitteeksi on kaiketi asetettava, että näiden peruskoulutuksen tuottamat valmiudet mahdollisimman hyvin vastaavat ammattikäytännön asettamia vaatimuksia? Mitä muita yleisiä ja erityisiä valmiuksia ammatti eri organisaatiomuodoissa ja tehtävissä vaatiikin, alalle suuntautuvien tulisi jo akateemisessa peruskoulutuksessaan perehtyä riittävän monipuolisesti ja relevantisti sekä aikuiskasvatuksen käytäntöön että teoreettisiin perusteisiin. Nykyisiin hastu-ohjelmiin sisältyy yleensä, jopa erityisinä opintojaksoina, jossakin määrin myös aikuiskasvatusta. Sen osuus on kuitenkin jo määrällisesti niin suppea, että senvertaista aikuiskasvatuksen tuntemusta tarvitsevat kaikki kouluhallinnonkin tehtävissä toimivat. Oppisisällöt ovat yleensä enemmän tai vähemmän sattumanvaraisia ja yksipuolisia. Lisäksi tulee kysyneeksi, missä määrin näistä opintojaksoista vastaavat opettajat itse ovat tutustuneet aikuiskasvatukseen.

Tarkoituksenani ei ole vaatia käytännön aikuiskasvattajalta kapea-alaisia ja pitkälle spesialisoivia tieteenalansa teoreettisia opintoja (nykyinen tutkintoasetus rajaa mielestäni koulutusohjelman muiden aineopintojen määrällisen osuuden liian ahtaasti ja joustamattomasti). Suurin osa ammatissa tarvittavista praktisista tiedoista ja taidoista taas opitaan parhaiten käytännön työn yhteydessä ja siihen liittyvin täydennysopinnoin. Väitän vain, että nykyisissä hastu-ohjelmissa aikuiskasvatuksen osuus on alalle suuntautumista ajatellen selvästi riittämätön. Mitä taas tulee nykyisen kasvatustieteen opintoihin - joihin sisällytän myös lapsuuden ja nuoruuden kehitys- ja kasvatuspsykologian, pitkälti samoin rajautuvan kasvatussosiologian, kouludidaktiikan ja koulusuunnittelun - niin niiden soveltamiskelpoisuus on aikuiskasvatuksen ammattitehtävissä varsin rajallinen, osin hyvinkin kyseenalainen.

Aikuiskasvatuksen laadulliseen kehittämiseen kuuluu olennaisena osana alan työntekijöiden koulutuksen suunnitelmallinen parantaminen. Kaikkein ensimmäiseksi olisi aikuiskasvattajien kouluttamisesta nyt saatava aikaan ennakkoluuloton ja mahdollisimman luotettava valtakunnallinen selvitys. Edellä on puhuttu alan määrällisen ja laadullisen koulutustarpeen arvioimisesta. Samassa yhteydessä olisi hyvä selvittää, mitä vaatimuksia ammattikäytännössä toimivat asettavat akateemiselle peruskoulutukselle. Selvitystä kaipaavat monet muutkin kysymykset. Sellainen on ammat issa jo toimivien täydennyskoulutuksen järjestäminen, mikä yliopistojen osalta koskee mm. niiden opetuskapasiteetin joustavaa ja tarkoituksenmukaista käyttöä. Edellä esittämästäni erottuu omaksi kysymyksekseen päätoimisten opettajien koulutus, mitä myös olisi selviteltävä, samoin kuin sivutoimistenkin opettajien kouluttamista.

Valtioneuvoston vuonna 1978 tekemässä aikuiskoulutuksen periaatepäätöksessä asetettiin yhdeksi tehtäväksi alalla työskentelevien koulutuksen kehittäminen. Parhaalta tuntuva tapa, jolla opetusministeriö nyt voisi tarttua tähän vuoroaan odottaneeseen tehtävään, olisi asiaa selvittävän, niin yliopistojen edustajista kuin hallinnon ja käytännönkin asiantuntijoista koostuvan toimikunnan asettaminen. 